\title{
BASIC takes bioremediation public
}

Officials at the US Department of Energy (DOE, Germantown, MD) are developing plans and dedicating funds for exploring the social implications and concerns raised by bioremediation research-a program provisionally named "BASIC (bioremediation and its social implications and concerns)." Although cast in much the same mold as the ethical, legal, and social implications (ELSI) component of the US Human Genome Project that is jointly supported by DOE and the US National Institutes of Health $(\mathrm{NIH}$, Bethesda, MD), the newer program is being designed to avoid some of ELSI's pitfalls, department officials say.

BASIC will be part of the department's natural and accelerated bioremediation research program (NABIR). Established this year with funding at $\$ 5$ million, the NABIR program is expected to double and perhaps triple in fiscal year (FY) 1997-in part by absorbing funds from other research programs that are being phased out, according to Jay Grimes of DOE, who says that the initial budget for BASIC in FY 1997 will be about $\$ 600,000$. He and Daniel Drell of DOE are codirectors of the program.

DOE's major environmental clean-up responsibilities include an estimated 2500 billion liters of contaminated liquids and 200 million cubic meters of contaminated solids, Grimes says. In mid-1995, an advisory panel recommended both that DOE should focus its efforts to deal with this massive problem around "field research centers" and that it form working research "partnerships" with investigators in industry and at universities. Toward this end, the department recently named three outside "science team leaders" and will shortly announce plans for choosing one or more such centers.

In planning this new program, participants realized that many of its findings, particularly site demonstration projects, would be "dead on arrival without serious consultation with affected communities," says Drell. Hence, the BASIC program, a concept that participants who attended a planning workshop held during July commended.

Although a major reason for initiating such a program is to anticipate and begin to address community concerns before actual problems arise, one unmistakable challenge facing DOE administrators is "making the case to scientists involved in NABIR that BASIC will be in their best interest," Drell says. "It can't work if it doesn't have trust from the scientific side of the program." He points out that although the ELSI program is funded at a steady $3 \%$ within the federal Human Genome Program budgets, "the
ELSI community has not done a good job explaining to scientists why it's needed."

Certainly there were a few signs during the mainly friendly July workshop that would-be bioremediators will face a variety of ELSI-style challenges. Tensions much like those Drell identified appeared occasionally. "The arrogance of scientists is a real problem," says workshop participant Janice Longstreth of the Waste Policy Institute (Washington, DC), "They need to communicate with the public and address issues at the local level."

But Burt Ensley, president of Phytotech (Monmouth Junction, NJ), sees it differently, "The arrogance of public advocates is much

\section{BASIC will be part of the} department's natural and accelerated bioremediation research program.

worse and of regulators, idiotic." He argues that, in applying for DOE support from the BASIC program, those investigating such issues should "face peer review every bit as rigorous as that for scientists." Longstreth and others responded by suggesting that researchers conducting fundamental and pilot studies subject their proposals to review not only by peers but also by community representatives. Clearly, unease exists among company representatives, regulators, and public advocates.

A further complication in this debate is the public's persistent lack of understanding about biotechnology-particularly as it touches on environmental issues, says Katherine Devine, publisher of Biotreatment News and a consultant for Devo Enterprises (Washington, DC). She outlined preliminary findings from a small opinion survey she helped to conduct under contract from two Canadian agencies, Environmental Canada and Industry Canada (Ottawa, Canada). According to the survey, Canadians are generally aware of biotechnology, but they tend to associate the term with health and food, rather than with environmental concerns or projects. Survey respondents also express "discomfort with genetic engineering, want independent oversight, but knowledge about biotechnology is minimal." Devine argues that programs such as DOE's BASIC that address stakeholder concerns could prove valuable because the "public expects to be consulted in establishing guidelines or codes of ethics for biotechnology."

Jeffrey L. Fox
Measure Binding Constants ำ

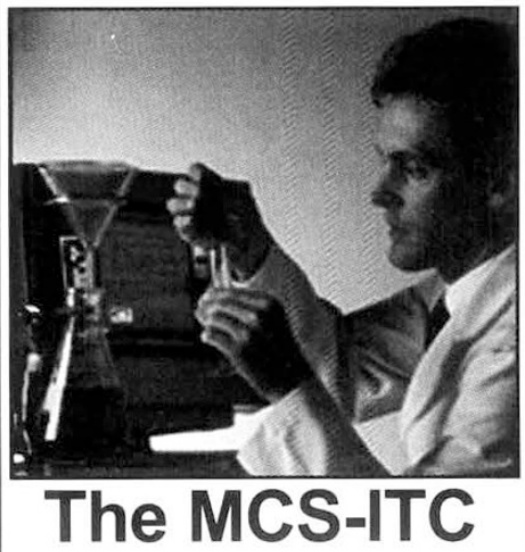

In Solution or Immobilized... You Decide!

Applications Include:

\section{Drug / Receptor Interactions}

* Protein / Ligand

* Protein / DNA

* Particle Surface Binding

* Binding to Lipid Vesicles

* Binding Anything to Anything Else

The MicroCalorimetry System
Isothermal
Titration

Calorimeter

NomicroGal
Incorporated

22 Industrial Drive East Northampton, MA

(800) 633-3115

(413) 586-7720 